\title{
АРХИВ
}

\section{Материалы обследования кафедры китайского языка ДВГУ, декабрь 1935 - январь 1936 годов. Часть 2}

\author{
DOI https://doi.org/10.24866/2542-1611/2021-2/129-146
}

Примечание:

Знак «"» в тексте источника заменён на знак «ъ»; исправления, внесённые в текст сразу после его написания, включены в публикацию. Исправлены однозначные опечатки и изъяты избыточные знаки препинания. Сохранён авторский грамматический стиль и способ написания слов. Все редакторские пометки и исправления помещены в квадратные скобки [ ]. Документы имеют перекрёстные ссылки, поэтому в части материалов проставлена оригинальная пагинация страниц в угловых скобках $<>$ в месте начала каждой страницы за исключением первой.

\section{№ 3}

\section{В Ы В О Д Ы \\ ПО ИТОГАМ ОБСЛЕДОВАНИЯ КАФЕДРЫ КИТАЙСКОГО ЯЗЫКА ВОСТОЧНОГО ФАКУЛЬТЕТА ДВГУ.}

На основе «Материалов по итогам обследования работы кафедры китайского языка Восточного факультета ДВГУ» мы помещаемздесьвыводы, сделанныев порядкесоответствующих разделов обследования (см. «Материалы» [документ № 1]: 1-18 разделы), и даем окончательное заключение.

Для удобства изложения материал разделен на две части: положительные и отрицательные выводы.

\section{1. ПОЛОЖИТЕЛЬНЫЕ ВЫВОДЫ.}

Раздел 1-й. Программы доведены до сведения студентов.

Раздел 2-й. $\quad$ 1. Преподавание теории разговорного языка (доц. Червонецкий) на 1, 2 и 3 курсах проходит в теоретической своей части вполне нормально.

2. Трудовая дисциплина групп на всех курсах удовлетворительна.

3. Преподаватель разговорной практики и письма т. Чжан обладает ценными положительными качествами для своей работы.

4. Состояние навыков в письменности у студентов удовлетворительно.

5. Студентами ведутся аккуратные записи преподаваемого материала.
Публикацию подготовил: Барбенко Ярослав Александрович, канд. ист. наук, доцент кафедры политологии Восточного института - Школы региональных и международных исследований, ДВФУ (г. Владивосток). Электронная почта: prohist@ya.ru

Продолжение. Начало см.: Известия Восточного института. 2021. № 1. C. 89-113.
Для изитирования:

Материалы обследования кафедры китайского языка ДВГУ, декабрь 1935 - январь 1936 годов. Часть 2 // Известия Восточного института. 2021. № 2. C. 129-146. DOI https://doi.org/10.24866/25421611/2021-2/129-146 
Раздел 3-й. $\quad$ 1. Преподавателем кафедры доц. Червонецким даны представителю обследования исчерпывающие данные о правильной теоретической разработке вопроса постепенного перехода от пассивного восприятия к самостоятельной работе студентов.

2. На уроках теории разговорного языка уделяется достаточное внимание письменным упражнениям.

Раздел 4-й. Кафедра регулярно на всех очередных заседаниях фиксирует свое внимание на отстающих студентах и добивается воздействия на них через треугольник Университета. [Вычеркнуто: «Существуют буксиры»] Проводятся консультации, как в установленном порядке, так и свыше указанной нормы (доц. Червонецкий).

Раздел 8-й. Н На заседаниях кафедры со студенческими представителями ведутся собеседования на темы о кружковой работе и о применении методов стахановского движения в работе студентов.

Раздел 14-й. Научными работниками кафедры ведется крупная, активная научно-исследовательская работа по составлению учебных пособий для студентов Востфака, а также для вневузовского употребления (пособие для нужд Армии).

Раздел 16-й. Подготовка к зачетной сессии идет планомерным порядком.

<Стр. 2> Суммируя сказанное о положительных моментах в работе кафедры, следует особо отметить большую эрудицию членов кафедры и их крупную [вычеркнуто: «научно-исследовательскую»] работу.

\section{2. ОТРИЦАТЕЛЬНЫЕ ВЫВОДЫ}

Раздел 1-й. 1. Во всех учебных программах отсутствует указание о дозировке иероглифики по данному курсу.

2. В программе по истории китайской литературы не видно увязки развития литературных течений с историческими градациями социально-экономического уклада жизни страны по отдельным этапам устройства государственно-политического строя. В новейшем периоде не отведено достаточно места пролетарской (революционной) литературе.

3. (К Учебной части). В деканате Востфака отсутствует учебно-производственный план и какой-либо программно-методический материал, а также рабочие планы.

4. Совершенно отсутствуют программы и какиелибо методические установки по разговорной практике и письму.

5. Составление учебного плана для 5-го курса проходило без тесной связи с председателем кафедры. 
Раздел 2-й. $\quad$ 1. На всех курсах отсутствует увязка подачи теоретического материала и разговорной практики, на которой должен фактически прорабатываться теоретический багаж знаний. Отсюда - бессистемная разговорная практика, вялость и пассивность на всех курсах.

2. Отсутствует контроль со стороны кафедры за работой молодого преподавателя т. Чжана.

[Вычеркнуто: «3. На 1-2 курсах в активной проработке материала участвуют преимущественно успевающие студенты (как на занятиях теории, так и на разговорной практике). Отстающие студенты по преимуществу обречены на пассивное восприятие.

4. На 2-м курсе имеет место чрезмерно большая дозировка иероглифики (80-110 знаков на шестидневку)»]. Отмечается поверхностная проработка текстов по газетному стилю.

5. В занятиях по теории разговорного языка на 3-м курсе и газетно-классическому стилям на 4-м курсе в силу самого метода преподавания отсутствует прививание студентам навыков самостоятельной работы. Перевод текста, записанный со слов профессора, преимущественно заучивается механическим путем. Отсутствует дифференцированный подход к возможностям роста студентов в учебе. Все это не дает базы для проявления студентами собственно инициативы в самостоятельной работе.

6. На 5-м курсе «Курс истории китайской литературы» излагается вне связи с социальным базисом и социальными сдвигами, имеющими место в Китае. Не делается критическая оценка взглядов буржуазных синологов на литературную революцию в Китае.

7. Прохождение на 5-м курсе методики преподавания китайского языка не соответствует по своему <стр. 3> содержанию целеустановке - подготовке кадров преподавателей китайского языка в средних школах Края.

8. Метод воздействия на студентов, проявляемый доцентом Червонецким при преподавании на 1, 2 и 3 курсах не способствует проявлению аудиторией соответствующей активности, а наоборот служит фактором к пассивности аудитории, как явлению общего характера.

9. На лекциях теории разговорного языка и разговорной практики отсутствует особое внимание преподавателя к отстающим студентам. Время, уделяемое на опрос каждого студента, дозируется неравномерно. Ответы студентов не получают аттестации в процессе самой работы. В результате на занятиях участвует лишь активная часть успевающих студентов. Особенная пассивность всей аудитории наблюдается на уроках разговорной практики на 1-2 курсах. 
Раздел 3-й.

Раздел 5-й.
9. На лекциях теории разговорного языка и разговорной практики отсутствует особое внимание преподавателя к отстающим студентам. Время, уделяемое на опрос каждого студента, дозируется неравномерно. Ответы студентов не получают аттестации в процессе самой работы. В результате на занятиях участвует лишь активная часть успевающих студентов. Особенная пассивность всей аудитории наблюдается на уроках разговорной практики на 1-2 курсах.

10. Методика разговорной практики на 1-2 курсах страдает однобокостью. Отсутствуют иные приёмы, кроме вопросов-ответов с инициативой со стороны преподавателя.

11. На занятиях 4-го курса по газетно-журнальному стилю отсутствует метод подачи литературно-обработанного перевода. Дословный же перевод не готовится студентами самостоятельно, а записывается под диктовку со слов профессора.

12. Не заостряется научно-исследовательский интерес студентов старших курсов над латинизацией китайской письменности, как актуальной проблемы грядущей культурной революции в Китае. Преподавание латинизации в текущем ак. году не ведется.

1. На втором курсе выражают недовольство по поводу отсутствия материала для самостоятельной проработки по газетному стилю.

2. Практически не осуществляется разработанная председателем кафедры установка по привитию студентам самостоятельных навыков в работе нед китайскими текстами.

Раздел 4-й.

По мнению студенческих представителей на 1-2 курсах т. т. Червонецким и Чжаном уделяется мало внимания отстающим студентам. Помощь им осуществляется по инициативе самих студентов.

Группы не вполне обеспечены учебниками. Несостоятелен метод переписки текстов через копировальную бумагу. На 2-м курсе немало времени отнимает у студентов переписка текстов. Студенты не ознакомляются со специальной литературой на иноязыках. Брошюра (речь т. Молотова), штудируемая на 3-м курсе - мало подходящий материал в силу диалектических [диалектных] расхождений в тексте. Ощущается не достаток в словарях. Неудачно выбрано пособие по изучению лит. стиля на 2-м курсе («Ударники полей». Мартынов) - трудность текста и большие дозировки иероглифики. 
Раздел 6-й. 1. Ненормальные явления резкой градации на 1-2 курсах всей группы не вполне успевающих и хронически отстающих, а также массового отставания на 3-м курсе. Все три курса, по заявлению доц. Червонецкого, подходят к зачетной сессии чрезвычайно неуверенно.

2. Вплоть до предзачетного периода наблюдалось массовое отставание и халатность студентов 3-го курса по отношению к работе у проф. Рудакова.

3. Преобладание метода пассивного восприятия фактор, способствующий невысокой успеваемости студентов.

<стр. 4> 4. Членом кафедры (доц. Червонецкий) констатируется отсутствие у студентов интереса и стремления к активности в своей учебе и наличие унылого настроения.

Раздел 7-й. За исключением нескольких попыток методологического характера со стороны доц. Червонецкого, кафедра не изучала систему и метод работы студентов. Передача опыта работы передовиков отстающим проводится преимущественно по инициативе самих студентов. Указаний как вести записки и конспекты не делается.

Раздел 9-й. Руководство дипломантами ограничивается на сегодня раздачей статей и тем. Отсутствие систематической работы с дипломантами наблюдалось на ряде прошлых выпусков.

Разд. 10-й. $\quad$ При достаточной работе кафедры по раздаче студентам заданий производственной практики и просмотру этих заданий с соответствующими отзывами не достает работы кафедры в области оперативного руководства в процессе самой практики.

Разд. 11-й. В В кабинете Востоковедения ощущается недостаток словарей и учебных пособий. Несмотря на ежегодные заявки со стороны кафедры на специальную иностранную литературу, таковая в течение ряда лет почти не получается. Научные работники кафедры лишены возможности читать современную китайскую литературу.

Разд. 12-й. Кафедрой не организован лингвистический кружок. Студенты крайне пассивно относятся к этому предприятию. Кафедра не привлекает наиболее успевающих студентов к научно-исследовательской работе под ее руководством. Отсутствует связь кафедры с соответствующими организациями по разработке проблем развития производительных сил Китая.

Разд. 14-й. Отсутствует связь с востоковедными институтами Москвы и Ленинграда. 
Разд. 17-й. Соцсоревнование с кафедрой японского языка (по примеру прошлого ак. года) не оформлено. В отношении имеющего место в практической научноисследовательской работе соцсоревнования членов кафедры не заключены письменные обязательства. Исключение представляет доц. Червонецкий, соревнующийся с научным работником кафедры японского яз. т. Юркевичем.

В дополнение к вышесказанному помещаем ряд выводов, представленных студенческим представителем т. Потаповым по итогам обследования кафедры:

1. Методы преподнесения учебно-производственного материала не приучает студентов к самостоятельной работе над материалом и заглушает собственную его инициативу.

2. Методические вопросы не стоят в центре работы кафедры.

3. Тематика прорабатываемого материала не всегда увязывается с современностью.

4. Нет борьбы со стороны кафедры за обеспечение студентов возможностями производственной практики.

$<$ стр. 5> 5. Кафедра не принимает участия в работе по концентрации китаеведческих сил вокруг кабинета Востоковедения.

\section{З А КЛЮЧЕНИЕ .}

Принимая во внимание солидную эрудицию членов кафедры и их многолетний педагогический опыт, мы вынуждены констатировать наличие в учебно-производственной работе кафедры моменты, идущие вразрез с основами советской методики преподавания иноязыков, нашедшими себе, между прочим, частичное отражение в следующих словах резолюции КПИЯ (Москва, 1932 г.):

«Неразрывность теории с практикой - обязательное условие правильной постановки преподавания иноязыков. Решающий фактор успеха здесь - активный характер изучения иноязыков с практическим применением получаемых знаний на каждом шагу с упором на навыки».

Недооценка этого и других стержневых положений советской методики преподавания иноязыков и имеющиеся налицо последствия этого явления приводят нас к заключению, что ряд моментов в учебно-производственном процессе работы кафедры организован СЛАБО и нуждается в перестройке.

Научный работник ДВГУ

(Феклин)

8 января 1936 г.

г. Владивосток

РГИА ДВ Ф. Р-289. Оп. 1. Д. 291. Л. 10-12. 
№ 4

\section{ПРЕДЛОЖЕНИЯ}

обследовательской бригады по итогам обследования работы кафедры Китайск. языка ВФ ДВГУ в 1935/36 акад. году.

1. Необходимо указание во всех языковых программах соответствующей дозировки иероглифики.

2. В программе по истории китайской литературы необходима (насколько это представляется возможным) увязка важнейших литературных течений с историческими градациями социально-экономической жизни страны. Полагаем необходимым отведение особого достаточного места пролетарской литературе.

3. Кафедре необходимо проработать программы разговорной практики и письма, снабдив их соответствующей методической установкой.

4. В занятиях по теории на 3-м курсе и газетно-классическому стилю на 4-м курсе, необходимо большее внимание кафедры в области прививания студентам навыков самостоятельной работы.

5. Желательно приближение преподавания методики китайск. языка на 5-м курсе по содержанию к своей непосредственной цели подготовке кадров преподавателей китайского языка в средних школах края.

6. Кафедре необходимо добиться возможности размножения учебных материалов более рациональным путем, чем переписка через копировальную бумагу или же непосредственное их переписывание в студенческие тетради.

7. Необходимо большее внимание со стороны кафедры выпускаемым в текущем году дипломантам.

8. Кафедре необходима организация лингвистического кружка.

9. В целях обмена научно-исследовательским и педагогическим опытом, желательна постоянная связь кафедры с востоковедными институтами Москвы и Ленинграда.

10. Необходима связь кафедры с заинтересованными в ее работе организациями Края.

11. Своевременная перемена курса педагогической работы кафедры в смысле основного упора на передовых студентов группы.

12. Для отстающих студентов необходима организация дополнительных консультаций с обязательной явкой.

13. Путем проверки личных записей студентов и др. методами кафедра должна изучать систему и метод работы студентов.

14. Оформить соц. соревнование с кафедрой японского языка.

15. Методические вопросы должны быть в центре повседневной работы кафедры.

Научный работник

(Феклин)

Студ. представители

(Денищенко)

(Потапов)

РГИА ДВ Ф. Р-289. Оп. 1. Д. 291. Л. 27-27 об. 
№ 5

Приложение.

\section{ПРАКТИЧЕСКИЕ ПРЕДЛОЖЕНИЯ.}

Заслушав сообщение профорга т. ВИЗИТЕЙ о ходе соцсоревнования в разрезе итогов учебы за ноябрь м-ц, Производственное Совещание 4-го курса кит. отд. Востфака отмечает:

1. Групповой договор полностью не выполнен. Индивидуальные договора в большинстве еще остались формальными и далеко не всеми выполнены и выполняются.

Больше того, многие студенты сорвали и срывают выполнение договоров плохой учебой. (Плохую оценку по 4 шт. имеют Беловицкий - 2, Козлов, Слюсарев, Глухов, Василенко, Ефремов - 1).

2. Многие студенты еще не начали писать (переводить) преддипломные работы.

3. Как результат неправильного метода преподавания у некоторой части студентов имеются иждивенческие тенденции, выражающиеся в дословном переписывании переводов, которые даются преподавателями и профессором, взваливая всю ответственность только на преподавателей за незнание грамматики изучаемых языков.

4. Наличие чрезмерной опеки над студентами со стороны профессоров и преподавателей (дословная диктовка переводов с кит. текста), отсутствие у ряда преподавателей, особенно по живой речи, кит. языка планов занятий. Методы преподавания кит. языка (деловой, газетный ст.) и английского языка не на высоте требований высшей школы.

5. Отсутствие стахановского метода как во всем учебной процессе, так и в самостоятельной работе каждого студента.

\section{Совещание ПОСТАНОВЛЯЕТ:}

1. Основной причиной плохих текущих оценок у известной части студентов 4 курса кит. отд. является отсутствие должного внимания и систематической самостоятельной работы над учебным материалом.

Поэтому, принимая во внимание их обещания об исправлении плохих оценок на более высшие оценки, Совещание предлагает треугольникам групп неослабно контролировать и в случае невыполнения взятых ими обязательств и решений группы - принять меры профсоюзного, партийно-комсомольского воздействия, вплоть до административных мер воздействия.

2. В связи с наличием явных недостатков в учебном процессе и в преподавании отдельных дисциплин,. Которые являются известным тормозом на пути поднятия качества учебы, Производственное Совещание выдвигает перед Деканатом, Учебной частью и кафедрами следующие практические мероприятия (предложения):

1. a) Учебной части за счет $10 \%$ отведенных учебным планом для консультаций консультационные часы включить в расписание помимо дней самостоятельной проработки до зачетной сессии.

б) В целях специализации каждого студента по определенному одному предмету специальности или по целому комплексу предметов и в целях привития навыков самостоятельной работы студентам (4-х курсов, которые этих навыков, к сожалению, не получили 
еще в стенах Университета) Учебной части совместно с деканатом и кафедрами пересмотреть учебный план в целях разгрузки уч. плана от несущественных предметов или уменьшения количества часов с соответственным увеличением предмету, который в оставшееся до окончания время принесет пользу в овладении языками, во-первых, и, во-вторых, в целях большего отведения консультац. часов за счет семинарских часов, которые зачастую и по ряду дисциплин носят исключительно характер отметочный (семинар для и ради исключительно отметок, напр. англ. и др.) и дать студентам больше возможности и времени для самостоят. работы под руководством кафедр и преподавателей.

2. Учебной части и деканату: а) Дать твердое указание преподавателям живой речи, чтобы они согласовывали объект живой речи с проходимым материалом по газетному и деловому стилям и военной терминологии.

б) Не загружать студентов переписыванием учеб. материалов и обеспечить необходимым количеством учеб. материалов.

в) Ввести на 4 курсе систематический курс китайской грамматики.

3. Перед кафедрами, в особенности перед кафедрой кит. языка, Совещание выдвигает следующие практические предложения, которые совещание и группы просят пересмотреть на внеочередных кафедрах (по согласованию с руководителями кафедр) с участием Зав. уч. ч., Декана Востфака и представителей группы.

1. По газетному стилю:

a) Общие статьи по газ. стилю не прорабатывать. Каждый студент самостоятельно работает над отдельной статьей по словарю под наблюдением проф. Рудакова.

б) Переводы подавать в письменной форме. Проверку проводить сразу же, результат и сам перевод возвращать.

в) Давать материал дифференцированно, по силам.

г) Оценивать знания студентов по самостоятельным переводам и грамматическим обоснованиям, которые студент дает к своим переводам.

2. По классическому языку.

а) Давать к каждому предложению его грамматическое обоснование.

б) Спрашивать не только перевод, но и грамматику.

3. По живой речи:

a) Кафедра должна дать темы, материал, над которым студенты должны будут работать. Дать установку т. Чжану - выправление произношения студентов, китайское построение предложения.

б) Иметь вопросно-ответную систему разговора (преподават. спрашивает - студент отвечает; студент спрашивает, преподаватель отвечает и т. д.), доклады не считать основным методом работы.

в) На каждом занятии каждый студент разговаривает.

4. По кафедре английского яз., сохраняя ныне существующие разделения по элементам, обратить внимание на то, чтобы не распыляться по мелочам и сосредоточить основное внимание на систематич. граммат. разборе тех или иных статей.

Газетные статьи подбирает преподаватель, причем учитывает его знание (по силе того или иного студента), определяет объем перевода 
1 См.: Известия Восточного института. 2021. № 1 . С. 90 , рис. 1 . за № [некоторый?] срок и проверить его работу, желательно переводы представлять письменно, а устно обосновать грамматикой.

Пересмотреть метод, систему проверки знания студентов в сторону более глубокого изучения того или иного студента и оказания методической помощи студенту в его самостоятельной переводческой работе. Упраздняя систему спрашивания для отметки и простого арифметического сложения массы отметок и выведения «некоей средне» отметки.

5. Кафедры должны руководить преддипломными работами студентов. Помочь студентам в выборе специальности на основе изучения его знаний, способностей и др.

Организовать научно-исследовательский кружок при кафедре кит. языка.

Треугольник

4-го курса кит. отд.: С. Ким, Визитей, Рось.

Верно:

РГИА ДВ Ф. Р-289. Оп. 1. Д. 291. Л. 13-13 об.

№ 6

\section{В УЧЕБНЫЙ ОТДЕЛ ДВГУ.}

В связи со смотром кафедры китайского языка нельзя не высказать некоторых пожеланий о некоторых возможных перераспределениях лингвистических дисциплин. Мы имеем в виду начинать изучение литературного языка со второго курса китайского отделения Восфака, вследствие трудности его изучения. В настоящее время он изучается, начиная с третьего курса, чем не достигается требуемый успех его прохождения. Вопрос о введении его со второго курса будет рассмотрен на одном из заседаний кафедры. Другим пожеланием является своевременная разработка первоначального пособия по литературному языку в сообществе с преп. Чжаном, который берется составлять примеры на классическом языке по различным темам современности. Методика такого пособия выясняется мною с учетом издаваемых в Китае учебных пособий этого рода.

В видах наиболее рациональной постановки дела на $\mathrm{V}$ курсе необходимо уже с весны приступить к изданию китайских текстов и учебных пособий всякого рода. Так нужно что нибудь издать на восковке по частной методике. Полезно было бы напечатать мою статью: о новом учебнике китайского языка, - если это не встретить возражений. Вместе с тем необходимо было бы что нибудь издать и по методике преподавания в средней и нисшей школе. Гола два тому назад, я в контакте с Червонецким составил докладную записку по этому вопросу, причем она было передана директору ДВГУ. Где находится эта докладная записка? Полезно было бы ее разыскать и приобщить к тому материалу, который собирается мною по этой дисциплине.

Проф. А. Рудаков

3/I 36.

РГИА ДВ Ф. Р-289. Оп. 1. Д. 291. Л. 14. 


\section{ДЕКАНУ ВОСФАКА}

Представляя при сем мои разъяснения по поводу статьи т. Потапова, я на основании фактического материала могу резюмировать их след. образом:

1. Организация учебного процесса кафедрой китайского языка вообще отвечает задачам подготовки высококвалифицированных советских специалистов.

2. Преподавание китайского языка ведется по методам высшей ориентальной школы, отнюдь не имея ничего общего с методами средней школы.

3. Картина преподавания, набросанная т. Потаповым, не соответствует действительности, представляя искажение фактов.

4. Высказывания относительно изучения оффициального языка неверны, вследствие непонимания предмета.

5. Вся статья т. Потапова представляет упражнение, слабо выдержанное в диалектическом отношении.

Зав. кафедрой кит. яз. Проф. А. Рудаков

$3 / \mathrm{I} 36$

ПРОФ. А. В. РУДАКОВ

В № 7 газеты: Трибуна Университета (25 декабря 1935 года) появилась статья: «Мы не школьники», подписанная фамилией: Потапов ${ }^{1}$. Оставляя в стороне некорректный тон статьи по отношению к преподавателю («поводырь», «нянька», «замахал руками») считаю полезным осветить некоторые темные места этого выступления в печати.

Вопрос касается IV курса китайского отделения Восфака, отличающейся наибольшей многочисленностью слушателей среди других курсов китайского отделения (14-15 человек к 1 янв. текущего года). Успеваемость в прошлом году была средняя - все больше тройку (уд.). В настоящем году к 1 янв. в процентном отношении она выражается следующими цифрами: по газетно-журнальному стилю: неуд. 14 2/7\%, уд. 57 1/7\%, хорошо - 28 4/7\%, по классическому языку: неуд $142 / 7 \%$, уд. 50\%, хорошо - 33 1/3\%. В смысле общеобразовательной подготовки курс оставляет желать много лучшего. Например. Отчет (в представленной первой редакции) студента Беловицкого пестрит грамматическими ошибками. Незнание русской грамматики и низкий уровень лингвистической подготовки вообе обнаруживается у многих, что сильно тормозит осмысленное штудирование китайских текстов. Кроме этого, невнимательность - почти поголовное явление. Напр. 14 декабря при чтении текста Лунь юй`я (III, 17) я дал довольно обстоятельное объяснение о китайском лунном календаре, рассылка которого находилась с некоторыми церемониями по случаю первого дня месяца. Когда 26 декабря при повторении дельно разобранного на прошлой лекции текста я задал вопрос о китайском календаре, то никто не мог сказать ни одного слова. И этот факт - не единичный. Особенно это заметно по тому, что объяснения по китайской грамматике проходят большею частью как-то бесследно для сознания уча- 
щихся этого курса. При грамматических объяснениях текстов я делаю ссылки на соот. $\$ \$$ практического словаря служебных слов, рекомендуя слушателям в обязательном порядке усвоить их путем самостоятельной проработки. В указанном пособии грамматическое правило ясно изложено на общепонятном русском языке; оно разъясняется многочисленными примерами, к которым дается транскрипция иероглифического текста и русский дословный перевод. Такой метод дает полную возможность усвоения грамматики китайского литературного языка. Насколько фактически добросовестно ведется самостоятельная проработка грамматики по пособию, видно напр. из того, что 29 декабря при чтении газетной статьи я обратился с вопросом к аудитории о значении служ. слова «цзэ», разъясняемого разговорным «цюеши». Разбор этого служ. слова происходил за две лекции тому назад, причем для самостоятельного ознакомления с ним был рекомендован $\$ 22$ пособия. Задавая вопрос об этом служ. слове я добавил, что в данный момент представляется возможность блестяще доказать, что самостоятельная проработка - не пустые слова, и что она продуктивно осуществляется. Однако никто не мог ответить на этот легкий вопрос, несмотря на то, что данное служебное слово имеет такие значения как: - а, но, же, наоборот, встречавшиеся уже неоднократно и ранее. Правда, нашлось 3 студента, которые заявили, что они читали, но забыли. Но как читали? Если бы при каждом правиле они внимательно разобрали два-три примера, то этого конечно не случилось бы.

Большой процент малоуспевающих студентов сильно тормозит темпы работы. Со стороны студенческих представителей неоднократно выставлялись настойчивые предложения исключительно работать с малоуспевающими (Василенко, Беловицкий, Глухов, Ефремов, Козлов, Рось, Слюсарев), причем моя работа с успевающими встречала протесты. Идя на встречу этим пожеланиям, приходилось значительную часть времени уделять слабым слушателям, что сильно задерживало нормальный ход курса.

Теперь своевременно объяснить основную цель преподавания китайского языка на IV курсе. Предмет, о котором будем говорить, - это стиль больших передовых статей, издающихся в Китае газет, выдержанных в строго классическом стиле китайского литературного языка, - <стр. 2> по различным вопросам современности. С особенностями этого, весьма сложного, языка слушатели впервые знакомятся на IV курсе, т. е. на втором году изучения литературного языка (вэньли), для удовлетворительного овладения которым китайцу нужно во всяком случае около десяти лет обучения - для того, чтобы научиться свободно читать и писать на нем. В нашем процессе изучения языка мы сокращаем это время до 4-5 лет, заменяя китайские учебные методы нашими на основе наших научно-лингвистических достижений, что ускоряет темпы его изучения. Притом наша задача значительно скромнее. Если слушатель научится со словарем читать текст, ясно представляя себе особенности грамматического строя, стиля, морфологии и семасиологии, то повидимому цель эта будет отчасти достигнута. Для более скорого и успешного овладения текстом у нас практикуется аналитический метод его освоения, работа над самим текстом посредством анализа входящих в него ингредиентов. Основное требование - это выработка дословного точного перевода на правильном 
русском языке. Но такой перевод дается преподавателем не сразу, но ему предшествует ряд объяснений 1) значений слов, как общих, так и в применении к данному тексту, причем обращается внимание на специальные фразы из клас. литературы, так наз.: дяньгу, 2) грамматического строя китайского предложения в зависимости от нахождения в тексте служ. слов в степенном порядке первоначальной ориентации на них, с переходом к объяснениям этих служ. слов и с ссылкой на соот. $\$ \$$ пособия; прежде чем приступить к окончательному русскому переводу делается экскурс в область русской грамматики с указанием особенностей идеоматики и др. выражения в этих двух языках, так разнящихся между собою в этом отношении. Только после такой всесторонней интерпретации текста, с учетом всех моментов языковонаучного характера, мы переходим к переводу его на русский язык. Какие при этом преследуются цели, мы повторим снова: дословность, точность и правильный русский язык. Но тут требуется неослабное внимание, возникает неспособность для некоторых воспринять все это в полноте, а потому, по нашему мнению, и являются выступления против таких методов ведения преподавателем проработок текстов.

Конечно интерпретация восточных текстов именно по специальным отделам китайской литературы, - от современных газетных и журнальных статей и до классического языка и произведений художественной литературы - должна занимать и фактически занимает существенное положение в общей схеме преподавания восточных языков как в наших специальных учебных заведениях так и заграницей. Такая интерпретация текста ведется высококвалифицированными научными силами, уже проведшими многие и многие годы над всесторонним изучением восточных языков их литератур, - теми научными работниками, которые путем продолжительного педагогического опыта вырабатывали специальные методы преподавания той или иной лингвистической дисциплины в связи с требованиями государства и общественной действительности и задачами данной школы. Насколько самый отбор научных работников для высшей школы строг и тщателен, - об этом не чего и распространяться.

Всякий, кто хоть сколько нибудь смыслит в методах преподавания китайского языка в высшей или средней, а тем более нисшей школы, никогда не сделает той грубой ошибки, которую позволяют себе т. Потапов и другие студенты, отождествляя наше преподавание с таковым же средней школы. В свое время кафедра китайского языка затратила не мало труда над разработкой методов преподавания китайского языка в нисших и средних школах нашего края, и мы должны разочаровать наших оппонентов, что между методикой высшей, нисшей и средней школ залегает очень большая пропасть.

В дополнение ко всему сказанному, мы не можем не притти к определенному выводу, что на первых порах (осенний семестр), когда еще только завязывается первоначальное осознавание предмета (в данному случае речь идет об усвоении литературного <стр. $3>$ стиля вэньли), самостоятельная проработка такого сложного в грамматическом и семасиологическом отношении текста должна давать очень мало при значительной, притом, затрате времени. Отыскивание по словарям, не только русским, но и иностранным, значительного количества незнакомых иероглифов, часто с выписыванием неподходящих к тексту значений; невозможность разобраться в синтаксических осо- 
бенностях языка, не встречавшихся ранее при изучении разговорного языка, и его идеоматике, должно приводить к весьма ничтожным результатам такую работу, и лучшим методом к пониманию таких текстов на первой поре изучения языка в наших Вузах считается аналитический метод и интерпретация текста, ведомые квалифицированным преподавателем.

Не можем не обратить сериозного внимания на одну специальную строну дела, - именно на учение о строе языка. Синтаксис кит. лит. яз., разработка которого ознаменовалась значительными успехами за последние годы, - этот синтаксис стал предметом моей научно-исследовательской работы, и объем его достигает до 500 стр. в рукописи, вследствие его необычайной сложности, богатству и разнообразию синтаксических особенностей, приближающих его к таким языкам, как напр. латинскому и древнегреческому. Интерпретируя тексты, я имею возможность отмечать не только различные общие схемы построения предложений, но и входить в детальные особенности конструкций, - без чего текст не может быть понят правильно. Из того, что у меня интерпретация текста проводится ясно, перевод кажется простым, - еще не значит, чтобы на самом деле все было так ясно и просто, и что мы, дескать, студенты можем и сами так прорабатывать. Дело в том, что многие грамматические правила, формулируемые мною, нередко представляют окончательный вывод - краткое резюме - грам. положений, суть которых изложена на многих десятках страниц. Спрашивается, откуда студенты без преподавателя возьмут эти правила? Разве только в процессе самостоятельной проработки у них явится представление о стройной системе китайского синтаксиса (это при плохом то знании русской грамматики) и разве будут правильны выводы в практическом его приложении к тому или другому тексту? Разве они уже имеют широкое представление о той исторической, бытовой и проч. обстановке, среди которой возникло определенное идиоматическое выражение (дяньгу)? Наконец, если преподавателю, вместо планового преподавания языка придется разменяться на мелкие консультационные справки, или что же - вместо одной лекции он должен прочитать 14 отдельных лекций по числу консультирующихся?

Предварительно принятия окончательных решений, надо зрело продумать и выяснить, не путем построения воздушных замков, а на имеющихся прецендентах [так], какие элементы курса требуют самостоятельной проработки, а какие - лекционной. Возьмем нынешний V курс. Проводилась самостоятельная проработка двух дисциплин: a) шицзина и б) китайских переводов речи т. Сталина на XVII съезде. В результате самостоятельной проработки шицзина успех был самый ничтожный: выбраны иероглифы, часто совсем не с теми значениями, которые должны подходить к тексту, причем никто не дал самостоятельного русского перевода. Потерянное таким образом время могло быть использовано с большей пользой на лишние лекции по истории китайской литературы, часы на которую отведены в незначительном количестве. Совсем другое представляла из себя вторая тема. Имея под руками русский текст речи, студенты имели возможность провести критическую работу над двумя китайскими переводами, выяснив, какой из вариантов этих текстов представляет наиболее правильный 
перевод, и вместе с этим провести самостоятельную работу по усвоению политэкономической и др. терминологии.

После столь обширного, но необходимого отступления, вернемся к затронутому выше обозрению того, как проходит лекция. Текст, проинтерпретированный указанным способом при наличии элементов вышеуказанного научного свойства, предлагается кому либо из студентов перевести самостоятельно с соблюдением основных требований: дословности, точности и на хорошем русском языке. Эта цель в большинстве случаев не достигается сразу; причиной этого являются: <стр. 4> 1) не вполне заостренное внимание, 2) плохое понимание грамматики вообще, 3) перескакивание с одного места текста на другой, через несколько иероглифов, без побудительной тому причины, 4) плохое овладевание сложными конструкциями текста чуждого, весьма своеобразного языка, благодаря чему смысл подлинника остается, вследствие плохого усвоения объяснений, скрытым за целым лесом иероглифов. Приходится неоднократно поправлять перевод, во второй или третий раз опять повторять то, что уже говорилось, если слушатель не в состоянии воспроизвести текст правильно на русском языке. Бывают и лучшие ответы, но это - значительно реже. Когда объясняется новый текст, слова преподавателя постоянно прерываются вопросами, задаваемыми различными студентами, причем определенные лица упорно делают ставку на те иероглифы, которые уже встречались неоднократно. Все это затягивает время и уменьшает объем материала, долженствуемого быть пройденным за данное время.

Теперь сравним учебную работу нынешнего IV курса с работой прошлогоднешнего IV курса. Выдающиеся студенты этого курса: Денищенко и Назаров. О темпах прохождения курса свидетельствуют достигнутые результаты под моим руководством. В начале года по оффициальному языку и скорописи (две различные дисциплины) прочитывалось по 1/2 страницы, через $2-3$ месяца - по одной и более, доходя до двух страниц, при обязательном повторении пройденного материала. По газетному стилю читались трудные статьи («Реформа высшей школы», «Маньчжурские партизаны» и проч.), причем за лекцию усваивался целый абзац 10-15 длинных строк печатного текста, вместо «трех» на разбираемом нами курсе.

На втором курсе в начале этого года мною прочитывалось 30-40 строк совершенно новой для студентов газеты: Рабочий путь. Опять совершенно не та картина, которая вырисовывается на IV курсе.

Бывали случаи проработки заданий с чисто стахановскими темпами на 200-300\%. Не могу при этом не упомянуть о работе студентки Денищенко, которая в течение 36 часов летнего семестра путем рационального сочетания самостоятельной работы с лекционной, прошла за этот короткий промежуток времени материал в таком объеме, с которым не справился бы наш IV курс за целый год. Об этом мы слушали доклад самой Денищенко на недавней конференции по поводу производственной практики.

Далее должно еще сказать об окончивших только что курс т. т. Медовой, Арсееве и Сидихменове. Кто посмеет сказать, что организация учебного процесса кафедрой китайского языка при подготовке их не отвечала задачам подготовки высококвалифицированных советских специалистов? Эти лица вышли с достаточным знанием 
языка и вполне подготовленные для ожидающей их деятельности в качестве лингвистов-восточников.

Должно отметить еще, что Медовая, в бытность студенткой, в качестве аспирантки, вместе с Загоруйко и Денищенко, по моей программе и под моим наблюдением и руководством, с Загоруйко прошла специальный курс языка, причем проработка шла очень быстрыми темпами (в несколько месяцев был пройден китайский учебник Отте в 100 с лишком страниц), приближающимися по выполнению заданий к стахановским методам работы. Денищенко, проходя у меня тексты по Рэтэю, вела самостоятельную проработку их, а у меня на лекциях всегда безоговорочно и быстро делала перевод с русского на китайский объемом в 1/2 страницы формата обыкновенной тетради, почти без ошибок. Она прошла таким образом почти всю синюю книжку издания т. Червонецкого. Разве это тоже не стахановский метод проработки задания? Так же работал и т. Загоруйко.

Я мог бы привести еще больше фамилий блестяще квалифицированных работников, окончивших курс Восфака по кит. отд., учившихся у меня, которые ныне работают в центре, и именами которых Восфак может поистине гордиться.

В заключение, не могу не упомянуть о моих бывших учениках: Хионине и Полевом, авторах известных словарей. От них я имею их печатные работы с надписями благодарности как своему бывшему учителю.

Полагаем, что приводимых примеров достаточно, чтобы понять весь инсинуирующий тон статьи т. Потапова. В этой статье все характерные <стр. 5> черты обстановки преподавания (характерные особенности курса) и самое преподавание на основе новейших достижений лингвистической науки тщательно затушеваны. Взамен этого получилась бездарно исполненная каррикатура с такими аксессуарами, как «трясущиеся коленки», и с прочей негодной, грубо намалеванной, бутафорией.

«Еще одно последнее сказанье, и летопись окончена моя». Остается дать еще разъяснение относительно изучения у нас китайского оффициального языка, в который вошли элементы литературного стиля вэньли. Важность изучения оффициального стиля видна уже из того, что на нем изложено современно китайское законодательство, и он охватывает, таким образом, все стороны экономической и политической жизни страны. Документы внутренней и внешней торговли, таможенные тарифы, правила о морском и речном судоходстве, портовые и лоцманские правила, уставы банков и все банковское делопроизводство, правила относительно торговых компаний и акционерных обществ, железнодорожные распоряжения, регулирующие эксплоатацию железных дорог, и в частности коммерческую и техническую эксплоатацию нашей бывшей КВЖД, законы о печати, вся консульская переписка - все это излагается на официальном языке в стиле вэньли. Оффициальные отделы в китайских газетах и журналах, литература по экономике, справочные издания также пишутся этим стилем.

Оффициальный стиль всех этих произведений представляет всесторонне разработанный язык, которым пользуются современные нам китайцы в течение многих десятков лет. Говорить о том, что язык документов сегодняшнего дня и язык документов 15-ти лет тому на- 
зад есть - один новый, а другой старый, - так же нелепо, как утверждать нечто подобное по отношению к русскому языку. Язык Ленина, своеобразный, гибкий и живой, - является для нас высоким образцом того, как должен писать и говорить советский деятель в наши дни. Этот язык долгое время будет служить неисчерпаемым источником, из которого русский стиль будет черпать свою энергию и силу.

Подобным же образом, мы имеем образцы китайского оффициального языка, относящегося к первым годам республики. Свод законов китайской республики и публикуемые ежегодно дополнения к нему составляют неисчерпаемый источник кит. оффициального языка с богатейшей терминологией по всем сторонам государственной жизни Китая. Такое же значение имеют и изданные в первые годы республики торговое, гражданское и уголовное право, игнорировать китайский текст которых мы не можем, если является практическая потребность работать в Китае по дипломатической и консульской службе. Изучая официальный стиль у нас, на Восфаке, (имея ограниченное число часов на эту дисциплину) мы должны охватить при минимуме материала наибольшее количество элементов терминологии, разнообразнейших форм документального характера в разностороннем воспроизведении жизни Китая, - судя по приведенному выше перечню материалов оффициального языка.

Можно ли достигнуть этой цели, если мы будем штудировать случайно подвертывающийся под руки материал, только потому, что он новый? В особенности - бумаги. Оппонент вращается только в орбите этих бумаг, не представляя себе, какой богатый материал для изучения лежит перед нами, ожидая нашего внимания, и как мало, в сущности, дает чтение одних только бумаг. Наоборот - нам нужен компактно составленный учебник этого языка с текстами по наиболее возможно разнообразному материалу. Тут должен быть всесторонне представлен и язык современного китайского законодательства, и язык отчетов о торговле, и язык указов и распоряжений центральной власти и переписки различных присутственных мест. Таможни, пути сообщений, законы о периодической прессе, почта и телеграф, сношения с иностранцами - все должно найти свое отражение в таком учебнике, все должно быть представлено соответствующими документами. Такой учебник возможно составить путем тщательнейшего отбора наиболее подходящих текстов среди сотен оффициальных документов, многие из которых представляют неодинаковый по ценности или негодности материал. (Учиться по случайно выхваченным из канцелярии бумагам и думать, что это и есть нечто самое настоящее - какая наивная мечта!) Но самое главное, - <стр. 6> автором такого учебника может быть только проживающее в Китае должностное лицо с солидным знанием китайского языка, канцелярия которого представляет большое собрание разнообразнейших материалов на китайском языке. Такое счастливое сочетание большого числа оффициальных документов с подбором языка, безконечно варьирующегося по своим оборотам и идеоматике и представляет небольшой, но компактный, учебник Отте, недаром пользующийся большой известностью и распространенностью. Мы конечно не возражаем против чтения той или иной новой бумаги, но основной лейтмотив изучения оффициального языка должен всетаки играть учебник Отте, и изъятие его из нашей учебной практики принесло бы непоправимый вред делу, раз это про- 
изошло бы по неосмысленному требованию некомпетентного лица, хотя бы и учащегося.

В заключение, говоря о статье т. Потапова, нельзя не признать, что он, не обладая ни соответственным педагогическим опытом, ни остаточными знаниями, старается, тем не менее, доказать, что в смысле опыта и знаний он выше квалифицированных работников, подменяя многолетний опыт своими умствованиями. Получившийся такого рода силлогизм представляет в логике своего рода reductio ad absurdum - приведение к абсурду, к нелепости. Таким образом, данная статья представляет собой слабое в диалектическом отношении упражнение. Но пусть т. Потапов поучится еще китайскому языку, поучится обуздывать свою самовлюбленность и почаще обращаться к самокритике, научиться зрело рассуждать диалектически, ну и тогда мы охотнее с ним будем полемизировать. Настоящее же упражнение статья Потапова - прибавляет еще несколько уродливых штрихов и черт - не скажу, чтобы особенно красивой - физиономии четвертого курса, относя на его актив литературное выступление такого рода.

Проф. А. Рудаков

3 января, 4 часа утра

19362.

РГИА ДВ Ф. Р-289. Оп. 1. Д. 291. Л. 15-18.

\section{Materials of the Inspection of the Chinese Language Department of Far East State University, December 1935 - January 1936. Part 2}

DOI https://doi.org/10.24866/2542-1611/2021-2/129-146

Publication is prepared by Yaroslav A. BARBENKO,

Ph. D. (in History), Associate Professor, Department of Political Sciences, Oriental Institute - School of Regional and International Studies, Far Eastern Federal University (Vladivostok, Russia).

E-mail: prohist@ya.ru

For citation: Materials of the Inspection of the Chinese Language Department of Far East State University, December 1935 - January 1936. Part 2 // Oriental Institute Journal. 2021. № 2. P. 129-146. DOI https://doi. org/10.24866/2542-1611/2021-2/129-146 